\title{
Hot Coffee for the Guest: Gastro Criticism on Budi Darma's Tamu
}

DOI:10.22515/ljbs.v6i1.2736

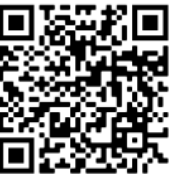

\author{
DIPA NUGRAHA \\ dipa.nugraha@ums.ac.id \\ Indonesian Language and Literature Education Study Program \\ Universitas Muhammadiyah Surakarta \\ Surakarta, Indonesia
}

submitted: 2/9/2020 revised: 7/2/2021 accepted: 2/4/2021 published: 30/4/2021 pages: 23-31

ABSTRACT Tamu (Guest) is a short story written by one of the most influential writers in Indonesia, Budi Darma. It depicts wedang kopi (hot coffee) serving tradition to guests in Java. Gastro criticism is used to reveal the significance of hot coffee serving in the short story. Close reading method is used to read and analyze the text. From the analysis, the short story reveals not just a tradition in the 1940-1950s of Indonesia on coffee and hospitality but also the effect on a man of the absence of hot coffee in his house when there is a woman in the house. Manggolo, one of the main characters in the story, feels insecure in his own house because he does not get served hot coffee he expects from his daughterin-law living under the same roof. Furthermore, this research suggests the possibility of combining gastro criticism and gender studies.

Keywords: gastro criticism, short story, coffee, Budi Darma

INTRODUCTION Indonesia has a long tradition of short stories published in newspapers. The history of short stories can even be drawn from the emergence of the print tradition at the end of the Dutch colonial period. In general, short stories published in leading newspapers in Indonesia according to Danerek (2013) are dominant with realism and factual. Although short stories published online have begun to appear, newspaper short stories, according to Danerek (2013), still hold literary hegemony in the short story. Thepresence of online short stories outside the publication of newspapers has not been able to shake up the position of short stories published on newspapers.

One of the senior Indonesian writers who has been actively writing short stories in Indonesian literary world for decades is Budi Darma. Unlike most of Indonesian short story writers, Budi Darma is well known for strange, surrealistic, and even absurdist stories (Hellwig \& Klokke 1985). Starting with writing short stories for magazines in the 70s and then for newspapers, he has been writing short stories in various newspapers' literature section ever since. Some of Budi Darma's short stories are Tamu (Guest, 2019), Lorong Gelap (Dark Tunnel, 2018), Tarom (2017), BukanMahasiswa Saya (Not My Student, 2017), Tukang Cukur (The Barber, 2016), Dua Penyanyi (Two Singers, 2015), Mata yang Indah (Beautiful Eyes, 2001), Derabat (1999), Gauhati (1996), and Kritikus Adinan (Adinan Critic, 1974).

In most recently published short story entitled Tamu, Budi Darma writes a story of the character of Manggolo who likes to visit people's homes and really likes to serve coffee that is made just right. Every time he visits, Manggolo often gossips about other people's wives based on their ability to brew coffee. This short story is interesting and relevant to be studied with a gastrocritical approach. Gastro criticism is an approach in literary studies that highlights or discusses the significance and/or implications of the presence of food or drink in a text. In addition, this research article is expected to enrich the treasures of Indonesian literary research by applying gastro criticism since gastro criticism has not been widely discussed in the world of Indonesian literature. 
THEORETICAL The approach used in this research article is gastro criticism. There are several FRAMEWORK names that can be considered as explorers in gastro criticism in literature, but the pioneer who laid the foundation of gastro criticism in literary studies is Ronald Tobin. Tobin is a professor in French literary studies who introduced the term to a food perspective approach in literary studies with the name gastrocriticism (gastro criticism) in 2002 which was later accepted by several literary academics in various parts of the world (Klitzing 2019). Another term in this approach, namely cytocriticism (cytos, wheat), which was introduced by Beatrice Fink in 1987, received less acceptance due to the lack of acceptance of the discussion about food when it is associated with literary studies (Pires 2012, 63-64; cf. Ellis 2017, 32). According to Tobin $(2002,24)$ gastro criticism is a multidisciplinary approach that links gastronomy and literary criticism.

Within the paradigm of Tobin's gastro criticism, there is a crossdisciplinary approach that links gastronomy and literary criticism through extensive exploration that can involve various branches of science such as sociology, anthropology, history, medical, semiotics, psychoanalysis, and philosophy in exploring food from its various aspects (Ellis 2017, 32; Klitzing 2019, 16). Meanwhile, according to Amy Tigner and Alison Carruth, the gastrocritical approach is a combination of cultural history studies, close reading, as well as literature review and literary concepts in marrying literary studies and food studies in an effort to find the influence of food traditions with the birth of literary forms. It can be simplified that gastro criticism is a study of rhetoric, symbols, meanings, and social, political, historical or other contexts related to food in a text (Klitzing 2019, 16-17).

In his study of the work of the Irish poet, Seamus Heaney, Klitzing (2019) shows that: (1) the representation of food from the type, production, to the name of commonly consumed food that appears in a work can become marker of time or period and marker the status of character; (2) changes in the way of producing and enjoying food can indicate changes in the surrounding environment and social and economic changes that occur in society; (3) food can be a representation and marker of a person's identity and status, personal choice, identity that is characteristic. collective (nationality, certain social groups), to identities formed from production processes and professions related to food (planting, breeding, harvesting, cutting, processing); (4) the tradition of consuming certain foods and drinks can be a marker of family traditions, groups, certain communities that can often be related to and or influence habits; (5) the practice of eating (or drinking) together which places individuals collectively in bonds and social traditions can be an indication of the acceptance or exclusion of a person in a group; (6) food can be associated not only with hunger (need biological) and taste (personal choice of matching the tongue) but also with lust, desire, and greed; (7) the availability of food can also be a sign of a fulfilled person's life while the absence of food can be a marker and or trigger feelings of contempt for a person because he fails meet their basic needs.

Food also influences change and signifies the social conditions of society (Ellis 2017, 38-39). Knowledge of food, both its effect on the human body, how to produce it, how to process it, how food is arranged and served at the dining table, and how to consume it, can be a discussion on the relationship between food and social conditions in a particular society. Food can be associated with the habits of a community as a marker of tradition and social solidarity, markers of belonging, collective identity, and one's status in society. 
Pires $(2012,63-64)$ believes that there is a link between food consumption behavior and social institutions as previously argued by Ronald Tobin in gastro criticism and Peter Farb in anthropology. Food is not only a marker of cultural and social identity. Furthermore, Pires $(2012,63)$ provides additional notes following the view of Bourdieu $(1984,190)$ that sometimes the taste and perception of the benefits of a food for the body by a person or group in a society, regardless of whether there is a scientific basis that supports it, depending on the idea about the status of class in society related to food and its benefits to the human body.

Talking about food is inseparable from the concept of inserting foreign objects into the human body that can provide certain sensations and effects to the body. Incorporating food is a state that makes you aware of the existence of self-conditions that can be unstable and change. Eating becomes a symbol of change (transformation) of the body both with regard to strength, purification, disease, healing, and survival so that eating becomes a marker of the fragility and dependence of human existence on something from outside the body (Kaplan 2012, 5; Ellis 2017, 36). Gastro criticism can also describe human gastronomic experiences that are associative with life experiences (joy, sorrow, challenge) and their role in building memories and perceptions about a place or city in a text. Food is also a theme that links a person to another in the context of certain relationships, such as work, love, spiritual, or even creative relationships to images of wandering and home as Biggs (2005) finds in Marilyn Hacker's poetry. This means that the discussion on food can relate to many aspects in human life.

RESEARCH This research is a qualitative research. The object of the study of the text in this METHOD research is the short story by Budi Darma entitled Tamu (The Guest). This short story was published in the Sunday edition of the Kompas newspaper on August 25, 2019.

In gastro criticism, the close reading method or sometimes the term extensive close reading is commonly used (Klitzing 2019, 16-17; Ellis 2017; Delville 2012; Biggs 2005). Careful reading is the method of reading text in literary studies that is most widely used and used in several approaches (Smith 2016; Culler 2010). Apart from being the most widely used method in the literary criticism tradition, close reading is distinguished from casual reading without the tendency to reveal ideology, certain discourse constructs in the text, the linkage of parts or the whole text to a certain context, and/or the work of criticism of the text. Techniques for data collection and analysis in close reading focus on 'words, sentences, or paragraphs' (cf. Nugraha \& Suyitno 2019, 607; Jänicke et al. 2015, 84) in the text relevant with gastro criticism.

RESULT AND Tamu presents a story told by the 'I' narrator about his neighbour and also his DISCUSSION landlord, Manggolo. The narrator of this short story has a wife named Tini. Tini is good at brewing coffee. Manggolo, the subject of the narrator's story telling, is an old man who has a successful son named Suroto. Suroto is great at photo studio business which has resulted in him becoming the sole player in the business in a small town named K. Suroto has a strange habit of taking photos of people who have been burned to death. Some of his shots are posted on a bulletin board in the town square. Even though he is successful, Suroto in this short story does not yet have a home, he still lives at 
Manggolo's house. Manggolo likes visiting people's homes as a guest and really likes to have coffee that is brewed just right from the host. He claims that he would die if he did not drink coffee at least twice a day. Every time Manggolo visit the narrator's house, Manggolo often gossips about other people's wives based on their ability to brew coffee. The habits of the Manggolo and Suroto in this short story are strange. Tamu confirms what is said by Tirto Suwondo and Harry Aveling about Budi Darma. Suwondo (2011, 110) concludes that Budi Darma's works are characterized by wild and nonsensical imagination. Aveling (2002, 99), on the other hand, states that the world presented by Budi Darma in his works is a world that is terrifying, very cruel, without humanity. Tamu closes with a comment from the narrator's wife, Tini, who is horrified, very cruel, and devoid of humanity. She hopes that Manggolo is burned to death in a locked house when he is striving for drinking coffee so much that later Suroto can take a photo of Manggolo's burnt corpse to be displayed in the town square.

At the beginning of the story, the narrator describes that he and his wife have just moved to the small town of $\mathrm{K}$. They rent a house whose Manggolo is its landlord. The time setting for the story is in the middle of June, 1950. Then the story develops to the description of Suroto, the son of Manggolo, who has a habit of photographing burnt corpses. Some of his photos are displayed on a bulletin board in the town square of K. Afandi (2019) reads this short story as Budi Darma's attempt to allude to the Madiun Affair in Indonesian history through some of these clues within the short story: M city, 1950, a Chinese language school, and Suroto who likes taking picture of burnt corpses and display them in the town square. This interpretation is interesting. However, there are several differences between the Madiun Affair incident and the details in Budi Darma's Tamu.

Madiun Affair was a rebellion orchestrated by PKI Indonesian Communist Party) in Madiun, a city in East Java. In September 1948, Munawar Musso led the establishment of the Indonesian Soviet Republic and proclaimed this republic as an independent state from the Republic of Indonesia. The perpetrators of the founding of the Soviet Republic of Indonesia carried out the kidnapping and massacre of kyai, government employees, and figures known as anti-communism (Susatyo 2008; Poeze 2011). The rebels were successfully crushed in less than a month by the Soekarno-Hatta government. Musso, while escaping undercover and escorted by only two of his confidants, was killed in Semanding Village, Sumoroto District, Ponorogo Regency, East Java on October 31, 1948. His body was photographed and then his photo was posted on a notice board to be identified by government officials summoned from Madiun who was considered to know Musso's face to ensure that the one who had been killed was really the leader of the Madiun Affair. This identification was important because not all members of the Indonesian army involved in the effort to fight the rebels knew Musso's true face.

There are three versions regarding the fate of Musso's body. The first version says that it was buried in an undisclosed place after Muso was killed (Dimjati 1951, 192). The second version states that Musso was shot in a public toilet in the Madiun area. His body was paraded to the town square of Madiun and deliberately used as a public spectacle in October 1948. The reason for the appearance of Musso's body in public was due to rumors circulating in the community doubting Musso's murder (Hakiem 2017). The third version states that Musso's body was photographed for further identification and then 
deliberately displayed to the public before being burned in the Ponorogo town square. Musso's body was burned because there was circulating news regarding the black magic held by some of PKI members that the decision to burn Musso's body emerged to prevent the resurrection of Muso (Wirayudha 2015). Of the three versions, for example Budi Darma's inspiration in establishing the setting for the fictional story Tamu, some parts do not correspond to the story of Musso's body. The small town of K, which is the background of the story in the short story Tamu, and the city where Suroto likes to take pictures of burning corpses for later displaying the photos in the town square is different from the initials of the city of Ponorogo or Madiun. $\mathrm{M}$ city, which can be considered reminiscent of the initials of Madiun in the short story Tamu, is told as the town where Tini, my character's wife, comes from. In addition, Suroto'shobby is to photograph the bodies of fire victims to be displayed in the square, while the story of Musso's body in one of the three versions shows a chronology of a person's corpse first photographed for identification purposes which is then burned in the town square because there is fear wrapped in myths of black magic. Despite the differences between Tamu and the Madiun Affair, Budi Dharma might have been inspired by the story of Muso in Madiun Affair to write Tamu as Budi Dharma is known to write Kritikus Adinan from the real story of HB Jassin, one of Indonesian literary critics.

Regarding coffee, this short story relates the story of coffee in Javanese context to two things: husbands who love drinking coffee and wives who make the coffee. This means that this short story can be read through gastro criticism perspective and gender studies approach. In gender studies, gender construction displays the division of space in a house (the domestic sphere) and the constructs of gender relations and roles between husband and wife in marriage. The house is nothing but a construct filled with gender stereotypes that illustrate the ideal expectations between husband and wife (cf. Duppé 2004, 11-16; Nugraha, Suwondo \& Suyitno 2020). In Tamu, coffee can be seen as vital in a household life.

Manggolo does not like his daughter-in-law, or Suroto's wife, because she keeps coffee in the locked cupboard so that Manggolo cannot enjoy coffee in his house. For some men like Manggolo, coffee is an important drink in life. It is so important that it makesManggolo claim that he would die if he did not drink coffee at least twice a day. Although it sounds absurd as Manggolo can buy coffee to brew and enjoy at home, the tradition of enjoying hot coffee brewed and served by women at home defines a normal life. Manggolo is disappointed of his daughter-in-law because she does not do what women in the house supposedly do. In traditional Javanese society, coffee is served as wedang (hot drink) by wives to husbands who have just returned from traveling or served to guests (Balai Bahasa Jawa Tengah 2017, 175, 279; Wibowo 2013). The role of the wife in the tradition of providing coffee treats is very important.

Women at home are the subjects in charge of preparing and serving food or drinks through the term masak (cooking) in Javanese society (Nugraha, Suwondo \& Suyitno 2020, 87-88). In the context of Tamu, the hot coffee is in the spotlight. Even if men in Java can enjoy hot coffee outside and are served by male sellers through the wedangan (drinking together) tradition (cf. Vera and Wihardi 2012, 62-63), women take on the role of hot coffee makers at home. This is the norm. This role of women in the house is taught from 
generation to generation in Javanese society from mothers to their daughters (Gunansyah 2017, 104) and from mother-in-laws to their daughter-in-laws (Wibowo 2013). Therefore, when Manggolo finds out that his daughter-in-law has never brewed and served coffee for him, Manggolo comes to a conclusion that his daughter-in-law is an evil woman, and worthy of being called a devil. He even believes that his daughter-in-law wants to kick him out of the house or learn some ways to eradicate him.

Being served hot coffee at home for a Javanese man like Manggolo, who is shown as a traditional character in Tamu by wearing sarong, beskap (traditional Javense suit), and blangkon (traditional Javanese cap), is a normal life when there is a woman in the house. Manggolo feels nervous that he does not live a normal life. He thinks that Suroto's wife is disrespectful to him.

Hot coffee is no longer interpreted as just a body warming drink. The willingness of women in the house to make coffee for men is a sign of normality in a house. A house where women are willing to make coffee for men in the house is a house that makes a Javanese man like Manggolo calm. Manggolo's uneasiness in his own house can be seen from Manggolo's habit of visiting neighboring houses every day. He visits neighbors asking for coffee, not in order to fill leisure time as is the urban tradition carried out by the leisure class in cafes in order to meet the needs of building social life and increasing the image of a lifestyle (cf. Solikatun, Tri Kartono \& Demartoto 2015; Said 2017). Coffee for Manggolo is a matter of a normal Javanese man's life.

When something that is considered normal is not found by someone, extreme conditions can occur, such as what happens to Manggolo. He becomes obsessed not only with the availability of the hot coffee drink at home but also with his mental judgement regarding women's ability to make good coffee. Manggolo's extreme level of associating hot coffee drink with women is found in the way he praises Tini, the narrator's wife and ridicules other wives in the neighborhood who are not good at making coffee.

"Your wife's hot coffee is the best, you know. She knows the right amount, how many spoons of coffee, how many spoons of sugar, the right cup size, and how long to boil the water. Markijan's wife, the neighbor over there, you know, it's a stupid. The cup is too big, the coffee is not strong enough. And Martono's wife, not far from Markijan's house, the water is definitely not hot enough anytime she makes hot coffee." (Darma 2019)

Manggolo does not stop at ridiculing the wives who are not good at making hot coffee, he also seems to underestimate husbands who ignore the importance of teaching or expecting their wives in making good hot coffee. Manggolo feels sorry that one of his neighbours, Martono, does not do anything knowing that his wife's hot coffee tastes so bad.

Manggolo's habit of enjoying hot coffee as a guest in the neighborhood is accompanied by his enjoying cigarettes served by the hosts. Manggolo, based on the narrator's story telling, always asks for coffee and cigarettes every time he visits his neighbor. In Java, coffee and cigarettes are not only commonly given to male guests but the combination of serving hot coffee and cigarettes also occurs when chatting with friends, staying up late, gathering at community events, after enjoying a meal, even during meetings related to religious activities (Setiawan \& Yoandinas 2013; Fimbriani 2011). Not only that, there are even a health myth in Java that coffee can be a remedy for the bad 
effects of smoking (Fimbriani 2011, 62-63). The hot coffee and cigarretes serving is something that was normal in the 1940-1950s. This leads to one part of gastro criticism that food and food-related habits such as meals and treats can be markers of habits that have occurred over time (cf. Klitzing 2019). However, this does not mean that Manggolo's habit of going around visiting people's homes in the neighborhood every day to get treats of hot coffee and cigarettes is normal.

The short story closes with the end of Manggolo's habit visiting the narrator's house. It starts with the disappointment of Tinito's failure in buying a land she aims to make for a duck farm. Wanting to open a duck farm is the main reason of the narrator and his wife, Tini, moving to the small town of $K$. They are deceived by a dodgy land broker who go missing with their money. Tini is so sad that she locks herself for days because of the incident. This means that no one is to make and serve hot coffee to any visiting guest. Manggolo is disappointed with the hot coffee he gets from the narrator's house. It tastes so bad. Manggolo is very disappointed that he makes promise not to visit again. Hearing Manggolo's promise, Tini unlocks herself from the room as she then bows and kisses the narrator's feet after Manggolo leaves their house.

What happens in the story represents real life situation. A guest in order to fill his spare time can repeatedly come to visit a house because he gets good treatment from the host. The stories told by the ' $I$ ' narrator about his life with his wife, Tini, and their experience of interacting with an annoying guest named Manggolo could just happen to anyone. Just because of great hot coffee, Manggolo has become a frequent visitor. From the perspective of the host, visiting guests who praise the treats given certainly makes the host proud. Especially in the case of Manggolo, although it is not featured in the story, the ' $I$ ' narrator is certainly proud to find that his wife Tini is better in making hot coffee than the other wives in the neighborhood according to Manggolo's saying. On the other hand, Tini who has the duty to brew and serve hot coffee to guests, feels the burden because of Manggolo's frequent visit. It is not surprising then that Tini feels grateful because the 'I' narrator, or her husband, fails to serve good hot coffee to Manggolo, so Manggolo promises not to visit again.

A close reading on Tamu shows that coffee is a drink for men served by women in the house. Women in the house are thus engaged in domestic activities tied to serving hot coffee to men in the house or male guests. According to the reading of the short story, the domestic role of women in the house related to hot coffee has a specific context. The context is Javanese society in the '50s. In this particular society and this specific time, coffee is served by women for men.

Coffee consumption is one of marks of masculinity as displayed in the short story. It has an association as a kind of energy drink for men or husbands who have just return home or as a stay awake and alert drink to male hosts and male guests in any conversation they have. Coffee consumption is a marker of masculinity because it is associative with the efforts to restrain sleepiness from men's activities (breadwinning activities) and enhancing work enthusiasm.

However, in the '90s there is a shift in the meaning of coffee consumption (Ambara 2014). In the ' 90 s, coffee consumption is not exclusive to men. Women are no longer the exclusive subjects in the division of domestic roles 
as coffee makers. Coffee consumption in the 1990s is not only an activity from enjoying drink made by women. Furthermore, technological developments and the expansion of the coffee market mean that coffee is now also served in the form of cold drinks or with ice.

Tamu, a short story set in the ' 50 s, shows that coffee becomes a marker of the practice of dividing roles between men and women in domestic space. The findings of coffee associations with gender, domestic space, and traditions according to the Javanese context from the reading of Tamu can complement the stories about coffee as this is not found yet, for example, in The Complete Book of Coffee (Rolnick 1982). The findings are also expected to contribute to the application of gastro criticism in Indonesian literary studies.

CONCLUSION Based on a close reading of Budi Darma's short story, Tamu, several things can be noted. First, the world of Tamu is a world of fiction, so suppose there is an assumption that Budi Darma uses a real incident in Madiun as a reference to some of the things he presents in his short story, this still does not shake the status of Tamu as a work of fiction. Second, Tamu puts coffee as a significant element in the development and course of the story based on the gastrocritical approach. Coffee as a treat for visiting guests and how to enjoy it together with cigarettes become markers of habits for a certain period of time in a society. Third, there is a link between the role of women in the domestic space in discussions regarding coffee and treats to guests. These findings show that gastro criticism and gender studies can be combined.

Afandi, Teguh. 2019. "Budi Darma Dan Tamu Menjengkelkannya." Basabasi.Co. https://basabasi.co/budi-darma-dan-tamu-menjengkelkannya/

Ambara, Janice. 2014. "Penerimaan Pemirsa Perempuan Terhadap Pesan Gaya Hidup Dalam Iklan-Iklan Kopi Dengan Endorser Perempuan." Jurnal E-Komunikasi 2 (1): 1-11

Aveling, Harry. 2002. Rumah Sastra Indonesia. Magelang: IndonesiaTera

Balai Bahasa Jawa Tengah. 2017. Kamus Bahasa Jawa Tegal-Indonesia. Semarang: Balai Bahasa Jawa Tengah

Biggs, Mary. 2005. "Bread and Brandy: Food and Drink in the Poetry of Marilyn Hacker." Tulsa Studies in Women's Literature 24 (1): 129-50

Bourdieu, P. 1984. Distinction: A Social Critique of the Judgement of Taste (Trans. Richard Nice). Polity Short Introductions. Cambridge: Harvard University Press

Culler, Jonathan. 2010. "The Closeness of Close Reading." ADE Bulletin 149: 20-25

Danerek, Stefan. 2013. "Cerpen Koran." Indonesia and the Malay World 41 (121): 418-38

Darma, Budi. 2019. "Tamu." Kompas, August 25

Delville, Michel. 2012. Food, Poetry, and the Aesthetics of Consumption: Eating the AvantGarde. New York \& Oxfordshire: Routledge

Dimjati, Muhammad. 1951. Sedjarah Perdjuangan Indonesia. Jakarta: Penerbit Widjaja

Duppé, Claudia. 2004. Poetic (Re)Negotiations of Home in New Zealand Women's Poetry of the 20th Century. Trier: Universität Trier

Ellis, Catherine Rose. 2017. Sex Work and Ingestion in Eighteenth-Century France. Durham: School of Modern Languages and Cultures, Durham University. http://etheses.dur.ac.uk/ 12629/

Fimbriani, Yovita Ika. 2011. Keyakinan Dan Nilai Penting Rokok Bagi Lansia Di Turi, Sleman, Yogyakarta (Kajian Konteks Perkembangan Rokok Di Indonesia). Yogyakarta: Fakultas Psikologi, Universitas Sanata Dharma

Gunansyah, Lovie Lenny. 2017. Aku, Perempuan. Yogyakarta: Stiletto Book

Hakiem, Lukman. 2017. "19 September 1948: Ikut Sukarno Hatta Atau PKI Muso!" Republika, September 18. https://republika.co.id/berita/owgah4385/19-september1948-ikut-sukarno-hatta-atau-pki-muso

Hellwig, Tineke \& Marijke J Klokke. 1985. "Focalization and Theme: Their Interaction in Orang-Orang Bloomington." Bijdragen Tot de Taal-, Land- En Volkenkunde 141 (4). [Brill, KITLV, Royal Netherlands Institute of Southeast Asian and Caribbean Studies]: 
Jänicke, Stefan, Greta Franzini, Muhammad Faisal Cheema \& Gerik Schevermann. 2015. "On Close and Distant Reading in Digital Humanities: A Survey and Future Challenges." In Euro Vis (STARs), 83-103

Kaplan, David M. 2012. Philosophy of Food. Berkeley: University of California Press

Klitzing, Anke. 2019. "My Palate Hung With Starlight: A Gastrocritical Reading of Seamus Heaney's Poetry." East-West Cultural Passage 19 (2). Berlin: Sciendo: 14-39. doi:https://doi.org/10.2478/ewcp-2019-0010

Nugraha, Dipa, Suwondo \& Suyitno. 2020. "Pembacaan Berperspektif Ekofeminisme Atas Sajak 'Isteri' Karya Darmanto Jatman." Kandai 16 (1): 77-95

Nugraha, Dipa \& Suyitno. 2019. "On the Beginning of Modern Indonesian Literature." Humanities and Social Sciences Reviews 7 (6): 604-16. doi:10.18510/hssr.2019.7691

Pires, Maria José Pereira. 2012. "Dealing with Appetites: Angela Carter's Fiction." Lisbon: Departamento de Estudos Anglísticos, Universidade de Lisboa

Poeze, HA. 2011. Madiun 1948: PKI Bergerak. (Trans: Hersri Setiawan). Jakarta: Yayasan Pustaka Obor Indonesia - KITLV-Jakarta

Rolnick, H. 1982. The Complete Book of Coffee. Hongkong: Melitta

Said, Irwanti. 2017. "Warung Kopi Dan Gaya Hidup Modern." Jurnal Al-Khitabah 3 (1): 3347

Setiawan, Sigit Budhi \& Marlutfi Yoandinas. 2013. Mereka Yang Melampaui Waktu. Yogyakarta: Pustaka Sempu \& INSISTPress

Smith, Barbara Herrnstein. 2016. "What Was Close Reading?: A Century of Method in Literary Studies." Minnesota Review 87 (1). Durham: Duke University Press: 57-75

Solikatun, Drajat Tri Kartono \& Argyo Demartoto. 2015. "Perilaku Konsumsi Kopi Sebagai Budaya Masyarakat Konsumsi: Studi Fenomenologi Pada Peminum Kopi di Kedai Kopi Kota Semarang." Jurnal Analisa Sosiologi 4 (1). Sebelas Maret University: 60-74

Susatyo, Rahmat. 2008. Pemberontakan PKI-Musso Di Madiun: 18-30 September 1948. Bekasi: Koperasi Ilmu Pengetahuan Sosial

Suwondo, Tirto. 2011. "Gauhati Budi Darma: Senantiasa Gagal Mengenali Jatidiri." In Membaca Sastra, Membaca Kehidupan, 109-14. Yogyakarta: Hikayat Publishing

Tobin, Ronald W. 2002. "What Is Gastrocriticism?" Dix-Septième Siècle 217 (4). Paris: PUF: 621-30. doi:10.3917/dss.024.0621

Vera, Nawiroh \& Doddy Wihardi. 2012. "'Jagongan Sebagai Bentuk Komunikasi Sosial Pada Masyarakat Solo Dan Manfaatnya Bagi Pembangunan Daerah." Jurnal IImiah Komunikasi Makna 2 (2): 40-46

Wibowo, Brigitta Agni. 2013. "Relasi Kuasa Dalam Komunikasi Keluarga Poligami (Analisis Kualitatif Terhadap Keluarga Dengan Relasi Pernikahan Poligami Pada Masyaraka† Muslim Di Kota Pekalongan)." Yogyakarta: Fakultas IImu Sosial dan IImu Politik, Universitas Atma Jaya. http://e-journal.uajy.ac.id/284/5/4KOM03630.pdf

Wirayudha, Randy. 2015. "Madiun Affair Buyar, Mayat Musso Dipamerkan \& Dibakar." Okenews, September 18. https://nasional.okezone.com/read/2015/09/17/337/ $1216346 /$ madiun-affair-buyar-mayat-musso-dipamerkan-dibakar

\section{ARTICLE CITATION IN THE CHICAGO MANUAL OF STYLE 16}

\section{In-text Citation}

Nugraha $(2021,26)$.....

..... (Nugraha 2021, 26)

\section{Reference List Entry}

Nugraha, Dipa. 2021. "Hot Coffee for the Guest: Gastro Criticism on Budi Darma's Tamu". Leksema: Jurnal Bahasa dan Sastra 6 (1): 23-31. https://doi.org/10.22515/ ljbs.v6i1.2736.

Copyright (C) 2021 Leksema: Jurnal Bahasa dan Sastra 